\title{
Role of Adolescents' Psychological Well-Being on Transmission of Domestic Violence
}

\author{
Aile içi Şiddetin Aktarmmnda Ergenlerin İyi Olus Halinin Rolü
}

\section{Emel Genç}

\section{Authors Information}

\section{Emel Genç}

Assistant Professor, Bartın

University, Bartın, Turkey

gncemel@,hotmail.com

\begin{abstract}
This study aims to investigate the psychological well-being as a potential moderator of the effects of childhood exposure to violence on the future risk of transmission of violence into romantic relationships. A sample of 3,193 participants from the National Longitudinal Study of Adolescent Health data was used to examine psychological wellbeing whether the link between exposure to violence in childhood and experiencing intimate partner violence in adulthood was disrupted. Findings showed a significant relationship between childhood exposure to violence and later perpetration and victimization of intimate partner violence. Further, adolescents' higher sense of wellbeing was negatively linked with the violent acts toward an intimate partner and the lower risk of victimization of intimate violence in adult relationships. While the proposed moderator did not interact with childhood exposure to violence to lessen the future risk of being violent or experiencing violence in the intimate relationship, wellbeing was linked with lower levels of violence in romantic relationships in adulthood. Conclusions suggest that clinicians should focus on how to improve the psychological well-being of adolescences to help prevent future IPV.
\end{abstract}

\begin{tabular}{l}
\hline Article Information \\
\hline Keywords \\
Adolescents \\
Exposure to Violence \\
Intimate Partner Violence \\
Psychological Well-Being \\
Transmission of DomesticViolence \\
Anahtar Kelimeler \\
Ergenlik \\
Partner Şiddeti \\
Psikolojik İyi Oluş \\
Şiddete Mağruz Kalma \\
Aile içi Şiddet Aktarım1 \\
Article History \\
Received: $02 / 12 / 2020$ \\
Revision: $29 / 07 / 2021$ \\
Accepted: 02/08/2021
\end{tabular}

\section{ÖZET}

$\mathrm{Bu}$ çalışmanın amacı, psikolojik iyi oluş halinin potansiyel moderatör rolünün çocuklukta şiddete mağruz kalmanın yetişkinlik döneminde şiddetin romantik ilişkilere aktarımı üzerindeki etkisini araştırmaktır. Ergen Sağlı̆ı̆nın Ulusal Boylamsal Çalışması verilerilerinden seçilen 3193 katılımcı ile psikolojik iyi oluş halinin, çocuklukta şiddete maruz kalma ile yetişkinlikteki partner şiddetini deneyimleme arasındaki ilişkiyi bozup bozmadığı incelenmiştir. Çalışma sonuçlarına göre çocuklukta şiddete maruz kalma ile ilerleyen yaşlarda partner şiddeti kurbanı olma arasında ilişki olduğunu görülmüştür. Ayrıca, ergenlerin yüksek iyi oluş hissine sahip olması ile partnerine şiddet uygulaması ve yetişkinlikte partner şiddetine mağruz kalması arasında negatif ilişki olduğu bulunmuştur. Her ne kadar önerilen moderatörün (psikoljik iyi oluş hali) çocuklukta şiddete maruz kalma ile yetişkinlikte partner şiddeti deneyimleme riski üzerinde etki etmediği bulunsada, iyi oluş halinin yetişkinlik döneminde partner şiddetine uğrama ihtimalini azalttığı bulunmuştur. Sonuç olarak, şiddet vakalarıyla çalışan uzmanlara, ergenlerin ilerde partner şiddeti uygulama veya maruz kalma riskini azaltmak için onların iyi oluş halini arttırmaya yönelik ugulamalar yapması önerilmiştir.

Cite this article as: Genç, E. (2021). Role of adolescents' psychological well-being on transmission of domestic violence. Turkish Psychological Counseling and Guidance Journal, 11(62), 297-312. https://doi.org/10.17066/tpdrd.1000612 


\section{INTRODUCTION}

Intimate partner violence (IPV) is defined as physically, psychologically, or sexually violent acts between intimate partners or spouses (World Health Organization [WHO], 2013). IPV is a widespread problem in the world and approximately 33\% of adult women experience at least one physical violence by their spouse in their lifetime (WHO, 2016). Considering that nearly $90 \%$ of domestic violence cases occur in a home setting (Fusco \& Fantuzzo, 2009; Miller- Graff et al., 2016), it is estimated that 176 million children (i.e., one in every four children worldwide) live with their families where the intimate partner violence has occurred (UNICEF, 2020). Previous research has reported that children's experience of violence in the home has been associated with various negative immediate and long-term effects that can be considered as serious damage to those children's emotional, psychological, as well as psychical wellbeing (Cater et al., 2015; Caykoylu et al., 2011; Maxwell et al., 2016). Additionally, violent acts observed or learned from the family can be transferred into an individual's adult life and lead them to become either being a perpetrator or victim of violence in their romantic relationship (Eriksson \& Mazerolle, 2015; Forke et al., 2018; Genç et al., 2018; Genç, 2020).

Despite the empirical support of a positive correlation between the experience of domestic violence (DV) in childhood and increased risk of perpetrating violence in a romantic relationship in adulthood, some researchers found inconsistent results and claimed that despite growing up in a violent home environment, some children showed resilience and were able to use adaptive coping skills (Anderson \& Danis, 2006; Izaguirre \& Calvete, 2015; Yoon et al., 2020). Additionally, the consequences of childhood exposure to violence in the home and individuals' responses to DV may vary depending on their personal, relational, and environmental/social factors. Therefore, it is essential to determine factors that are important for the development of efficient interventions to prevent the transmission of DV intergenerationally. In this study, adolescents' psychological well-being as a protective factor on DV transmission was examined, considering its important role in promoting personal growth and one's behavior control (Ugur et al., 2015).

\section{Theoretical Framework}

The vulnerability stress adaptation model (VSA; Karney \& Bradbury, 1995) was used to explain and support this study's results. According to the VSA, three interconnected factors (i.e., enduring vulnerabilities, stressful life events, and adaptive process) influence individuals' relational process and their relationship stability over time. The first factor, enduring vulnerabilities refers to unchangeable factors of a person such as personality traits, race, family, and personal history. Second, stressful life events describe any challenges that people may encounter anytime in life such as economic difficulties, health problems, and life transitions. Lastly, the adaptive process refers to the ways that navigate people for better interaction and behavior toward each other when they encounter a conflict or problems. Enduring vulnerabilities and experiencing stressful life events disturb individuals' behaviors and attitudes negatively and may destroy their romantic relationships. However, the third factor, the adaptive process can help how individuals and couples adapt in later life. Throughout these three components of the VSA model, individuals can adapt their reactions or behaviors to reduce the risk of IPV perpetration and victimization.

For this study, the terms of individual enduring vulnerabilities were used, as experiencing family violence in childhood; stressful life events indicated exposure to IPV; and the adaptive process was considered as 
having a protective factor (i.e., psychological well-being). Although exposure to family violence in childhood usually harms individuals and their relationships, protective factors (e.g., psychological wellbeing) can enhance positive adaptation in the context of adult intimate relationships. In other words, vulnerabilities may lead the individuals to become more aware of the violence that occurs at home and use their inner sources (i.e., protective factors) to repair the effects of being exposed to family violence, which may lead to healthier intimate relationships.

\section{Effects of Early Experience of Domestic Violence}

The negative impacts of exposure to DV in childhood have been commonly studied in the last two decades. According to previous research, individuals who were witnessed or been directly exposed to violence in childhood developed psychological and behavioral problems (López-Soler et al., 2017; MacDonell, 2012). Specifically, there was a high risk for anxiety, depression, stress, and trauma (Boeckel et al., 2017; Lyold, 2018; Silva et al., 2019), lower performance at school (McDonald et al., 2016), and behavioral problems including hostility, aggression, and delinquency for these children (Lyold, 2018; Paterson et al., 2008). Additionally, previous longitudinal studies claimed that the harmful effects of exposure to DV in childhood continued to manifest in adulthood (Cater et al., 2015; Genç et al., 2018; Miller-Graff et al., 2016). It might influence children's manners toward the use of violence and increase the odds of being a victim or perpetrator of violence in their romantic relationships (Eriksson \& Mazerolle, 2015; Forke et al., 2018; Genç et al., 2018).

While plenty of studies investigate the impacts of violence and its intergenerational transmission, inconsistencies exist in the literature that not all children who experienced violence at home appear to suffer from the same devastating outcomes (Anderson \& Danis, 2006; Forke et al., 2019; Kitzmann et al., 2003). Some research revealed that children who witnessed DV at home experienced neither short term nor long term consequences (Forke et al., 2019; Kitzmann et al., 2003), and those children were able to show a high level of resilience (Anderson \& Danis, 2006; Howell et al., 2010; Izaguirre \& Calvete, 2015). Studies began to focus on the factors that potentially protect children from the adverse effects of exposure to DV at home (Bowen, 2015; Genç et al., 2018; Howell et al., 2010; Miller- Graff et al., 2016). Previous studies found that positive parent-child relationship (e.g., Miller- Graff et al., 2016), support from peers and community (Genç et al., 2018), and intervention programs were beneficial in promoting psychological adjustment and resilience among children exposed to DV (McDonald et al., 2016; Sargent et al., 2016).

Previous literature on the resilience and exposure to IPV identified three major factors (i.e., support from family, support from peers and individuals attributes) as protective factors, which can moderate the relationship between childhood exposure to violence and its harmful consequences (e.g., CopelandLinder et al., 2010; Genç et al., 2018). For the present study, psychological well-being was used as a possible moderator. It was questioned whether or not having a positive attitude toward one's self, such as believing that one's being worthy, possessing good qualities, and accepting life as it is, might be an important protective role in mitigating the negative outcomes of the early experience of DV. Although a limited number of studies paid attention to children's psychological well-being for coping when living with DV, this study aimed to investigate whether the psychological well-being of children may protect themselves from the future perpetration or victimization of intimate partner violence. 


\section{Psychological Well-Being and Experiencing of Violence}

Psychological Well-Being. Psychological well-being is a comprehensive and adaptable concept. The World Health Organization (WHO) offers a description of well-being that includes life satisfaction, happiness, morale, and a person's positive self-concept (WHO, 2014). Similarly, well-being is defined with three facets: positive affect, absence of negative affect, and satisfaction with life (Moore \& Diener, 2019). Although previous research found the negative association between psychological well-being and IPV (Callahan et al., 2003; Montero et al., 2011; Escribà-Agüir et al., 2010), there is a lack of research regarding how adolescents perceived well-being can mitigate the adverse effect family violence experienced on the transmission of IPV. In this study, psychological well-being was conceptualized as individuals' positive states about themselves, which included having self-esteem, feeling worthy, and happiness in life. The combination of psychological well-being was explained below:

Self-esteem. Self-esteem was defined as being aware of one's strengths, qualities, and having a positive image of self (Walker \& Knauer, 2011). Previous studies showed a strong correlation between self-esteem and DV (Cameranasi et al., 2020; Gonzalez-Guarda et al., 2013; Matheson et al., 2015; Papadakaki et al., 2009). Specifically, studies claimed that children who witnessed or were exposed to domestic violence were at an increased risk for low self-esteem (Cameranasi et al., 2020; Matheson et al., 2015; Papadakaki et al., 2009; Tajima et al., 2011), and low self-esteem was linked to aggressive manners (Teng et al., 2015). Furthermore, low self-esteem was linked with being a victim or acting violently toward the partner (Karayagiz Muslu et al., 2020; Papadakaki et al., 2009; Skee, et al., 2016). However, self-esteem can be a protective factor and used to cope with DV (Edwards et al.,2011; Genc et al., 2018). It was claimed that people who had high self-esteem tend to feel confident in romantic relationships and experienced less psychical or emotional abuse (Edwards et al., 2011; Skeen et al., 2016). Although childhood exposure to violence at home led to having a lower level of self-esteem, these children were able to improve their self-esteem in time by receiving social support or doing activities that they are good at (Milner \& Baker, 2017; Richard \& Branch, 2013) consequently, it can protect them against the continuation of violence.

Self-worth. Although self-esteem and self-worth are related topics, self-worth can be defined as the satisfaction and acceptance of oneself in terms of achievements and personal features (Lim et al., 2012). In other words, self-worth may be viewed as individuals' positive feelings about themselves while selfesteem can be viewed as individuals' positive thoughts about themselves. Low self-worth was associated with anger problems, aggressive behaviors (Murphy et al., 2005; Copeland-Linder et al., 2010), and negative self-perception, which can contribute to IPV (Holt \& Gillsepie, 2008).

Previous studies found that self-worth was negatively affected by exposure to family violence during adolescence (Smith, 2011; Trocme \& Wolfe, 2001). However, having emotional and social support from parents and close friends could help to develop self-worth for them and protect young adolescents from the stressors, and buffer the negative effects of living in a violent environment (Li et al., 2007; Riesen \& Porath, 2004).

Life satisfaction. Life satisfaction, also known as happiness, was studied as a cognitive component of well-being (Callahan et al.2003). A few studies focused on the relationship between life satisfaction and IPV victimization and perpetration and revealed that exposing or witnessing the DV was linked to low life satisfaction (Hamama \& Arazi, 2012; Fulu et al, 2013; Lambert et al., 2014). Additionally, low life satisfaction may lead to increased vulnerability of IPV victimization (Callaha, et al., 2003; Lepistö et al., 
2010). Even though experiencing violence at home was found to be negatively correlated with the quality of life, some studies claimed that some factors such as close peer relationships, community, and family support, and sense of belongingness increased adolescents' life quality and helped them to perceive their life experiences positively (Miller-Graff et al., 2016; Yıldırım \& Çelik Tanrıverdi, 2020). Additionally, previous studies found that a positive outlook on life lessened behavioral problems and decreased the level of stress, aggression, and hostility (Bendayan et al., 2013), and increased social and emotional competence and healthier adjustment (Al’Uqdah, 2010; Bendayan et al., 2013; Arslan \& Çoşkun, 2020; Yıldırım \& Çelik Tanrıverdi, 2020).

As an important component of psychological well-being, it was expected that adolescents who have higher life satisfaction would experience less violence in adulthood, despite their reports of experiencing violence in the family of origin.

\section{Present Study}

Identification of factors that are protective against the impacts of DV exposure may offer possible prevention strategies, which could be better the course of a child's development following exposure. Thus, the present study aimed to examine the potential moderating role of adolescents' psychological well-being on the association between childhood experience of violence in the family and future involvement of violence in adult intimate relationships. It was hypothesized that psychological well-being, as a latent concept, would be linked to a lower chance of exposing and perpetrating IPV in later romantic relationships, and it would moderate the relationship between early exposure to violence and future perpetration and victimization of intimate partner violence.

\section{METHOD}

\section{Participants and Procedures}

Longitudinal data from the Adolescent Health Survey (ADD Health) was utilized for this study. The national study of ADD health is a longitudinal study of a nationally representative sample of over 20,000 adolescents in the 7th through 12th grade in the US in 1994-95. Those adolescents were followed from early adolescence to adulthood with four in-home interviews: the first in-home interview and in-school survey conducted in 1994-95 (Wave I), the second follow-up interviews were in 1996 (Wave II), the third was in 2001-02 (Wave III), and the last interview was in 2008-09 (Wave IV) when the Wave I respondents were 24 to 32 years old. The data set involves demographic questions as well as social, economic, psychological, and physical health situations. Further, survey questioners include subjects about the participants' family, community, and school dynamics, as well as their attitudes, expectations, and risk behaviors.

For the present study, the data from Wave I, Wave III, and Wave IV with a sample of 3,193 participants (1447 male and 1746 female) were used to assess the variables used for the present study. All respondents in the sample reported being in a relationship- about $65 \%$ of the participants were married, $19 \%$ were cohabiting, and 15\% were dating. Considering the education level of participants, a large number of participants attended college with $49 \%$ of the sample possessing a bachelor's degree $(12.4 \%$ received an associate degree). Approximately a quarter $(26 \%)$ of the participants stated a yearly income less than $\$ 5,000$, about a third $(36 \%)$ of the participants indicated an income between $\$ 20,000$ and $\$ 39,999$, and just $10 \%$ of the participants stated their income between $\$ 40,000$ and $\$ 74,999$. 


\section{Ethical Statement}

The author declare that they continue to work in accordance with scientific study ethics and the Helenski declaration in this study. Accordingly, the research was reviewed by the Human Research Ethics Committee of Bartin University and was given permission (2020-SBB-0248).

\section{Measures}

Childhood exposure to violence. Experiencing violence in the family at early ages was measured with a question of "How often their parents or other adult caregivers slapped, hit, kicked, or neglected them by the time they started the sixth grade" at Wave III and the response categories were coded between $0=$ this has never happened and $5=$ more than 10 times.

Perpetration of IPV. Participants' perpetration of psychical or sexual violence toward their partner was asked the rate of experiencing violence at Wave IV with 4 questions (e. g., "how often did/have you slap/slapped or kick/ kicked your partnerftable?, how often did you insist/insisted on or made/ make your partner have sexual relations with you when he/she didn't want to?') at Wave IV. The items were coded between $0=$ never and $7=$ more than 20 times in the last year of the relationship. The alpha coefficient was $\alpha=.83$.

Victimization of IPV. Participants' exposure to IPV was measured at Wave IV by 4 questions that asked about the frequency of psychical and/or sexual violence that was committed by the current partner (e. g., "how often have/did you had/have an injury, such as a sprain, bruise, or cut because of a fight with your partner?", how often has/did your partner insisted/insist on or made/ make you have sexual relations with him/ her when you didn't want to?"). Scores were re-coded to 0 indicating no victimization experience and 1 as experiencing victimization. The alpha coefficient was .67 .

Psychological well-being. This includes three main components: a) self-esteem, which was measured by the statements "you have a lot of good qualities", "a lot to be proud of", "just as good as other people" $(\alpha=76)$; b) self-worth, which was measured by statements "you feel wanted and loved", "you feel socially accepted" $(\alpha=.60)$; and c) life satisfaction, which was measured by "you are bappy", "enjoyed life", "feel hopeful about future" at Wave I $(\alpha=.70)$. Response categories were coded between 1 (strongly agree), and 5 (strongly disagree). Higher scores on this scale represented a higher level of psychological well-being.

\section{Data Analysis and Processing}

Logistic regression was tested if the proposed moderator could potentially mitigate the expected association between the exposure to violence in childhood and later risk of perpetration and victimization of IPV considering the binary nature of how perpetration and victimization of IPV were coded. Wellbeing as a protective factor was considered as the latent variable that could have a direct effect on acting violently and exposure to violence in adulthood. Data were run with IBM SPSS Version 22 and Mplus (Muthen \& Muthen, 1998). For the estimated model, fit indices are not reported, because Mplus does not run the fit indices when dichotomous or categorical variables are used in the analysis. Maximum Likelihood (ML) was used to assess the estimate parameters and missing data (Acock, 2005) for the proposed model. 


\section{RESULTS}

\section{Correlations}

Descriptive statistics for the entire sample are presented in Table 1. Correlations among all variables were reported in Table 2. The correlation between exposure to violence in childhood and future victimization of IPV $(r=.068, p<.01)$ and perpetration of IPV $(r=.094, p<.01)$ was statistically significant. Additionally, there was a negative correlation between exposure to violence in childhood and self-esteem $(\mathrm{r}=-.07, \mathrm{p}<.01)$, self-worth $(\mathrm{r}=-.09, \mathrm{p}<.01)$, and life satisfaction $(\mathrm{r}=-.07, \mathrm{p}<.01)$. Similarly, the correlation between perpetration of IPV in adulthood and self-esteem $(\mathrm{r}=-.05, \mathrm{p}<.01)$, self-worth $(\mathrm{r}=$ $-.07, \mathrm{p}<.01)$, and life satisfaction $(\mathrm{r}=-.06, \mathrm{p}<.01)$ were negatively statistically significant. While there was no statistically significant correlation between victimization of IPV in adulthood and self-esteem and self-worth, victimization of IPV was negatively correlated with life satisfaction $(r=-.06, p<.01)$.

\begin{tabular}{lllll}
\hline \multicolumn{2}{l}{ Table 1. Descriptive statistic for study variables $(\mathbf{n}=\mathbf{3 1 9 3})$} & & \multicolumn{2}{l}{} \\
\hline Variables & $\boldsymbol{M}$ & $\boldsymbol{S D}$ & Range & $\boldsymbol{\alpha}$ \\
\hline Initial Violence & .72 & 1.43 & 5 & - \\
Perpetrator of IPV & .17 & .37 & 1 & .83 \\
Victimization of IPV & .24 & .42 & 1 & .67 \\
Self-Esteem & 8.6 & 1.2 & 8 & .76 \\
Self-Worth & 8.4 & 1.27 & 8 & .60 \\
Life Satisfaction & 8.3 & 2.63 & 12 & .70 \\
\hline
\end{tabular}

\begin{tabular}{|c|c|c|c|c|c|c|}
\hline Variables & 1 & 2 & 3 & 4 & 5 & 6 \\
\hline 1. Initial Violence & - & & & & & \\
\hline 2. Perpetrator of IPV & $.094 * *$ & - & & & & \\
\hline 3. Victimization of IPV & $.068^{* *}$ & $.495^{* *}$ & - & & & \\
\hline 4. Self-esteem & $-.069 * *$ & $-.052 * *$ & -.021 & - & & \\
\hline 5. Self-Worth & $-.094 * *$ & $-.071 * *$ & -.034 & $.595^{* *}$ & - & \\
\hline 6. Life Satisfaction & $-.072 * *$ & $-.65^{* *}$ & $-.060 * *$ & $.423^{* *}$ & $.408^{* *}$ & - \\
\hline
\end{tabular}

$* * p<.01$ (two-tailed test).

\section{Logistic Regression Result}

Logistic regression analyses were utilized simultaneously in a path analysis with main effects and interaction effects to test the moderation effects in this model (represented in Figure 1). The odds ratio (OR) was used to interpret the results from the model, provided in Table3. All path coefficients between predictors and outcomes were included in the model. Results indicated that the exposure to domestic violence in adolescence increased the probability of adult perpetration by $23 \%(\mathrm{~b}=.29, \mathrm{p}<.001$, OR = 1.23), and victimization by $15 \%(b=.14, \mathrm{p}<.05, \mathrm{OR}=1.15)$. Further, higher psychological well-being was associated with a $14 \%$ decrease in the likelihoods of becoming a victim of IPV in future $(\mathrm{b}=-.15, \mathrm{p}$ $<.05, \mathrm{OR}=.86)$ and a $26 \%$ decrease in the risk of becoming a perpetrator of IPV $(\mathrm{b}=-.20, \mathrm{p}<.001$, OR $=.74)$. While there was a main effect between adolescents' well-being and lower levels of IPV in adult relationships, psychological well-being did not moderate the association between exposure to family violence in childhood and future violence in adult romantic relationships. 


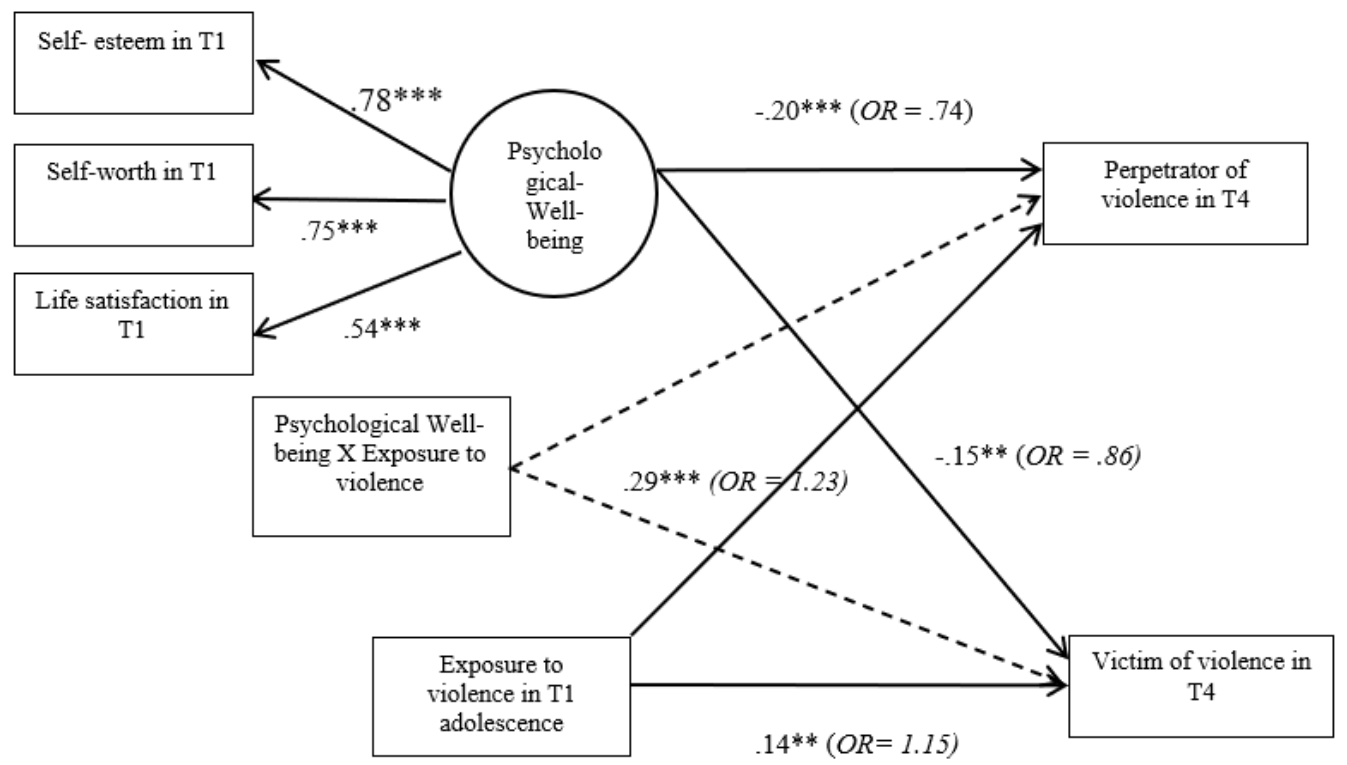

Figure1. Psychological well-being and Transmission of IPV Model. Model is just-identified. T1 =Wave 1; T4 = Wave 4 .

$* * * p<.001$ (two-tailed).

\begin{tabular}{lllllll}
\hline \multicolumn{2}{l}{ Table 3. Path analysis predicting perpetration and victimization of IPV in adulthood (n= 3193) } \\
\hline & \multicolumn{2}{c}{ Perpetration of IPV } & \multicolumn{4}{c}{ Victimization of IPV } \\
\hline Variable & \multicolumn{1}{c}{ SE B } & OR & $b$ & SE B & OR \\
\hline Childhood violence & $.29^{* * *}$ & .049 & 1.23 & $.14^{* *}$ & .045 & 1.15 \\
Well-being & $-.20^{* * *}$ & .08 & .74 & $-.15^{*}$ & .069 & .86 \\
Childhood Violence $x$ Well-being & .057 & .067 & 1.059 & -.002 & .063 & .998 \\
\hline${ }^{*} p<.05 .{ }^{* *}<<.01 . *^{* *}<<.001$ (two-tailed) & & & & & &
\end{tabular}

\section{DISCUSSION}

The current study examined the moderating effect of psychological well-being on the association of being exposed to family violence during adolescence and later risk of involvement of violent acts in a romantic relationship and exposure to violence by a partner. Although the offered moderator in this study did not interact with childhood exposure to violence to lessen the future risk of violent behaviors or experiencing violence in the intimate relationship, it was found that well-being as the main effect was linked with lower levels of IPV in adult intimate relationships.

Further, the study results revealed that the relationship between reported early exposure to DV and later violent behaviors was positively correlated. Specifically, exposure to family violence in childhood was more like to increase the possibility of both IPV perpetration and victimization in adult relationships. While the transmission of IPV literature has mixed results, the results of this study were consistent with the former studies, which claimed that exposure to violence in childhood causes the transmission of violence in future romantic relationships (e.g., Eriksson \& Mazerolle, 2015; Genç et al., 2018). 
Additionally, it was claimed a notable direct association, which also was highlighted in former research. Based on the study results, individuals with a higher level of psychological well-being (i.e., a higher level of self-esteem, self-worth, and life satisfaction) were less likely to be both victims and perpetrators of IPV. This result was supported by the previous research, which revealed that a higher positive selfconcept (i.e., feeling valuable, accepted, and worth loving) was related to lower aggression within an intimate relationship (Bendayan et al., 2013; Walker \& Knauer, 2011). Likewise, it was found that low self-esteem and lesser psychological well-being can result in victimization and perpetration in a romantic relationship (e.g., Callahan, et al., 2003; Papadakaki et al., 2009) and perpetration and victimization of IPV are related to lower life satisfaction (Hamama \& Arazi, 2012; Fulu et al, 2013; Yount et al., 2016). According to Al'Uqdah's study (2010), individuals who were satisfied with their life were more likely to have social and emotional competence that led to less violent behavior and healthier adjustment. The lower risk of being a perpetrator and victim of IPV can also be explained by the VSA model, which emphasizes that individuals can adapt their behaviors to counterweight their enduring vulnerabilities. In other words, once individuals have a positive concept about themselves (e.g., trust their abilities and themselves, feeling loved and positive), they are less likely to respond aggressively and negativity to what others have said or seen about them (Bendayan et al., 2013; Holt \& Gillsepie, 2008; Miller-Graff et al., 2016).

The current study also suggests that secure, confident, and happy individuals are less likely to behave violently. Further, these positive individual traits may develop a stable character that possesses selfcontrol. Thus, they may be better suited to adapt to stressful situations and develop effective strategies to deal with problems. These protective factors may assist them in facing stressors and threats in their relationships and preventing them from engaging in IPV.

\section{Limitations and Future Directions}

The finding of this study should be considered within the context of the following limitations. First, the reporting bias can be considered an important limitation, since the measures used in this study were from participants' self-reports. This can be an issue when working on a socially undesirable behavior and participants may underreport, which could cause lower estimates of the link with early experiencing to IPV and later IPV perpetration or victimization. Second, there was not a specific or standardized measurement to assess IPV in the ADD health data set. The questions about early experiencing violence in the home mostly related to being neglected and/or experiencing physical violence. Further, participants were not asked whether they witnessed, observe, were involved in (directly or indirectly), or about the frequency of parental IPV. Finally, the measure of parental violence was collected retrospectively. Namely, participants (ages 18-24 years) were asked at Wave III if they exposed violence at home in their childhood, after a significant time gap. There was a high chance that this measure may have been manipulated by current events, which might lead to recall bias during the survey (Cui et al., 2013).

Future studies should include a broader source of measurement and assessment approach than that used in the current study. Additionally, interaction with important others, such as parents, peers, and teachers, may have an impact on the psychological well-being of young adolescents. Therefore, it would be beneficial to test the extent of relationship quality with others moderates the relationship between the early exposure to family violence and later IPV victimization and/or perpetration, particularly given the differences between females and males. 


\section{Clinical Implications}

To enhance intervention with adults and youth who have been exposed to DV in their family of origin, practitioners and policymakers need a better understanding of factors that may alleviate the effects of children's violence exposure on later outcomes. The results of the present study provide several implications for the prevention of IPV. As clinicians work to reduce current violence and future violence, our results suggest focusing on adolescents' psychological well-being (i.e., self-esteem, worth, and life satisfaction). Therefore, interventions should seek to assist adolescents and emerging adults to gain a greater degree of psychological well-being as a mechanism for preventing future violence in relationships. Goal-directed forms of therapy, including solution focus, and cognitive-behavioral therapies would be helpful to increase the confidence, mood, and quality of relationships of adolescents.

Additionally, the humanistic-existential approach could be useful to enhance these positive traits. This approach emphasizes acceptance, caring, and positive (affirming) feedback, which also helps individuals work toward finding their values (Tan \& Wong, 2012). Once, adolescents can value and accept themselves as worthy and worthwhile without conditions, feeling well-being naturally improves, which can help to manage the stresses in life in a healthy way.

Another way to improve psychological well-being is to have an accepting and supportive social environment. Thus, adolescents' relationships with their peers and being part of a social group could help them to build better self-belief and foster positive feelings about themselves.

\section{Conclusion}

Transmission of violence is a serious problem all over the world. Using 3,193 participants across 14 years, psychological well-being was tested as a moderator, which might interrupt the relationship between experiencing violence in childhood and the involvement of violence in adult romantic relationships. This study results showed a substantial association between exposure to violence in childhood and both perpetration and victimization of IPV in adulthood. Furthermore, the risk of IPV in adulthood was negatively linked with well-being (i.e., self-esteem, self-worth, and life satisfaction) during adolescence. Although psychological well-being was used as a proposed moderator, there was no interaction with early exposure to violence at home to decrease the future possibility of acting violently or exposure to violence in intimate relationships, a direct effect was identified that was linked with lower levels of victim and perpetrator of IPV in adult relationships. 


\section{REFERENCES}

Acock, A. C. (2005). Working with missing values. Journal of Marriage and Family. 67 (4), 1012- 1028. https://doi.org/10.1111/j.1741-3737.2005.00191.x

Al'Uqdah, S. N. (2010). The relationship of exposure to community violence among parents' psychological distress, satisfaction with life, parental socialization of emotions, \& preschoolers' social-emotional competence. (Doctoral Dissertation). Retrieved from PsycINFO. (Order No. AAI3404501).

Anderson, K. M., \& Danis, F. S. (2006). Adult daughters of battered women - Resistance and resilience in the face of danger. Journal of Women and Social Work, 21(4), 419-432. https://doi.org/10.1111/j.17413737.2005.00191.x

Arslan, G., \& Coşkun, M. (2020). Student subjective wellbeing, school functioning, and psychological adjustment in high school adolescents: A latent variable analysis. Journal of Positive School Psychology, 4(2), 153-164. https://doi.org/10.47602/jpsp.v4i2.231

Bendayan, R., Blanca, M. J., Fernández-Baena, J. F., Escobar, M., \& Trianes, M. V. (2013). New empirical evidence on the validity of the satisfaction with life scale in early adolescents. European Journal of Psychological Assessment, 29(1), 36-43. https://doi.org/10.1027/1015-5759/a000118

Boeckel, M. G., Wagner, A., \& Grassi-Oliveira, R. (2017). The Effects of Intimate Partner Violence Exposure on the Maternal Bond and PTSD Symptoms of Children. Journal of Interpersonal Violence, 32(7), 1127-1142. https://doi.org/10.1177/0886260515587667

Bowen, E. (2015). The impact of intimate partner violence on preschool children's peer problems: An analysis of risk and protective factors. Child abuse \& neglect, 50, 141-150. https://doi.org/10.1016/j.chiabu.2015.09.005

Callahan, M.R., Tolman R.M., \& Saunders, D.G. (2003). Adolescent dating violence victimization and psychological well-being. Journal of Adolescent Research. 18(6):664-681. https://doi.org/10.1177/0743558403254784

Cameranesi, M., Piotrowski, C. C., \& Brownridge, D. A. (2020). Profiles of adjustment in children and adolescents exposed to intimate partner violence: A scoping review investigating resilience processes. Journal of Positive School Psychology, 4(1-Sup1), 117-136. https://journalppw.com/index.php/JPPW/article/view/175

Cater, A. K., Miller, L. E., Howell, K. H., \& Graham-Bermann, S. A. (2015). Childhood exposure to intimate partner violence and adult mental health problems: Relationships with gender and age of exposure. Journal of Family Violence, 30(7), 875-886. https://doi.org/10.1007/s10896-015-9703-0

Caykoylu, A., Ibiloglu, O. A., Taner, Y., Potas, N., \& Taner, E. (2011). The correlation of childhood physical abuse history and later abuse in a group of Turkish population. Journal of Interpersonal Violence, 26(1), 34553475. https://doi.org/10.1177/0886260511403748

Copeland-Linder, N., Lambert S. F, \& Ialongo N. S. (2010). Community violence, protective factors, and adolescent mental health: A profile analysis. Journal of Clinical Child \& Adolescent Psychology. 39(2):176-186. https://doi.org/10.1080/15374410903532601

Cui, M., Ueno, K., Gordon, M., \& Fincham, F. D. (2013). The Continuation of Intimate Partner Violence from Adolescence to Young Adulthood. Journal of marriage and the family, 75(2), 300-313. https://doi.org/10.1111/jomf.12016

Edwards, K., Gidycz, C., \& Murphy, M. (2011). College women's stay/leave decisions in abusive dating relationships: A prospective analysis of an expanded investment model. Journal of Interpersonal Violence, 26, 1446-1462. https://doi.org/10.1177/0886260510369131

Eriksson, L., \& Mazerolle, P. (2015). A Cycle of Violence ? Examining Violence, Attitudes, and Intimate Partner Violence Perpetration. Journal of Interpersonal Violence, 30(6), 945-64. https://doi.org/10.1177/0886260514539759

Escribà-Agüir, V., Ruiz-Pérez, I., Montero-Piñar, M. I., Vives-Cases, C., Plazaola-Castaño, J., Martín-Baena, D., \& 
G6 for the Study of Gender Violence in Spain (2010). Partner violence and psychological well-being: buffer or indirect effect of social support. Psychosomatic Medicine, 72(4), 383-389. https://doi.org/10.1016/j.aprim.2016.03.006

Forke, C. M., Myers, R. K., Fein, J. A., Catallozzi, M., Localio, A. R., Wiebe, D. J., \& Grisso, J. A. (2018). Witnessing intimate partner violence as a child: How boys and girls model their parents' behaviors in adolescence. Child abuse \& neglect, 84, 241-252. https:// doi.org/10.1016/j.chiabu.2018.07.031

Forke, C. M., Myers, R. K., Localio, A. R., Wiebe, D. J., Fein, J. A., Grisso, J. A., \& Catallozzi, M. (2019). Intimate Partner Violence: Childhood Witnessing and Subsequent Experiences of College Undergraduates. Journal of interpersonal violence. https://doi.org/10.1177/0886260519860909

Fulu, E., Jewkes, R., et al., (2013). Prevalence of and factors associated with male perpetration of intimate partner violence: Findings from the UN Multi-country cross-sectional study on men and violence in Asia and the Pacific. The Lancet Global Health, 1(4), pp.e187-e207. https://doi.org/10.1016/S2214-109X(13)70074-3

Fusco, R. A., \& Fantuzzo, J. W. (2009). Domestic violence crimes and children: A population-based investigation of direct sensory exposure and the nature of involvement. Children and Youth Services Review, 31(2), 249-256. https://doi.org/10.1016/j.childyouth.2008.07.017

Genç, E. (2020). Integrated model of intimate partner selection for repeating cycle of violence. A. Balciogullari \& M. C. Sahin (Eds.), Current Studies in Social Science II. (pp.1-14). Akademisyen Kitabevi

Genç, E., Su, Y., \& Durtshi, J. (2018). Moderating factors associated with interrupting the transmission of domestic violence among adolescents. Journal of Interpersonal Violence. 36(9-10). https://doi.org/10.1177/0886260518801018

Gonzalez-Guarda, R. M., Vermeesch, A. L., Florom-Smith, A. L., McCabe, B. E., \& Peragallo, N. P. (2013). Birthplace, culture, self-esteem, and intimate partner violence among community-dwelling Hispanic women. Violence against women, 19(1), 6-23. https:// doi.org/10.1177/1077801212475336

Hamama, L., \& Arazi, Y. (2012). Aggressive behaviour in at-risk children: Contribution of subjective well-being and family cohesion. Child \& Family Social Work, 17(3), 284-295. https://doi.org/10.1111/j.13652206.2011.00779.x

Holt, J. L., \& Gillespie, W. (2008). Intergenerational transmission of violence, threatened egoism, and reciprocity: A test of multiple psychosocial factors affecting intimate partner violence. American Journal of Criminal Justice, 33, 252-266. https://doi.org/10.1007/s12103-008-9036-0

Howell, K. H., Graham-Bermann, S. A., Czyz, E., \& Lilly, M. (2010). Assessing resilience in preschool children exposed to intimate partner violence. Violence and Victims, 25, 150-164. https://doi.org/10.1891/08866708.25.2.150

Izaguirre, A., \& Calvete, E. (2015). Children who are exposed to intimate partner violence: Interviewing mothers to understand its impact on children. Cbild Abuse \& Neglect, 48, 58-67. https://doi.org/10.1016/j.chiabu.2015.05.002

Karney, B. R., \& Bradbury, T. N. (1995). The Longitudinal Course of Marital Quality and Stability : A Review of Theory, Method, and Research, 118(1), 3-34. https://doi.org/10.1037/0033-2909.118.1.3

Kitzmann, K. M., Gaylord, N. K., Holt, A. R., \& Kenny, E. D. (2003). Child witnesses to domestic violence: A meta-analytic review. Journal of Consulting and Clinical Psychology,71,339-352. https://doi.org/10.1037/0022006x.71.2.339

Lambert, M., Fleming, T., Ameratunga, S., Robinson, E., Crengle, S., Sheridan, J., Denny, S., Clark, T., \& Merry, S. (2014). Looking on the bright side: An assessment of factors associated with adolescents' happiness. Advances in Mental Health, 12(2), 101-109. https:/ / doi.org/10.1080/18374905.2014.11081888

Lepistö, S., Åstedt-Kurki, P., Joronen, K., Luukkaala, T., \& Paavilainen, E. (2010). Adolescents' experiences of 
coping with domestic violence. Journal of Advanced Nursing, 66(6), 1232 1245. https://doi.org/10.1111/j.1471-6712.2010.00792.x

Li, S.T., Nussbaum K. M., \& Richards M. H. (2007). Risk and protective factors for urban African American youth. American Journal of Community Psychology. 39(1):21-35. https:// doi.org/10.1007/s10464-007-9088-1

Lim, B. H., Adams, L. A., \& Lilly, M. M. (2012). Self-worth as a mediator between attachment and posttraumatic stress in interpersonal trauma. Journal of Interpersonal Violence, 27(10), 2039-2061. https://doi.org/10.1177/0886260511431440

López-Soler, C., Alcántara-López, M., Castro, M., Sánchez-Meca, J., \& Fernández, V. (2017). The Association between Maternal Exposure to Intimate Partner Violence and Emotional and Behavioral Problems in Spanish Children and Adolescents. Journal of Family Violence, 32(2), 135-144. https://doi.org/10.1007/s10896-0169864-5

Lloyd, M. (2018). Domestic violence and education: Examining the impact of domestic violence on young children, children, and young people and the potential role of schools. Frontiers in Psychology, 9,2090. https://doi.org/10.3389/fpsyg.2018.02094

MacDonell, K. (2012). The combined and independent impact of witnessed intimate partner violence and child maltreatment. Partner Abuse, 3(3), 358-378. https://doi.org/10.1891/1946-6560.3.3.358

Matheson, F. I., Daoud, N., Hamilton-Wright, S., Borenstein, H., Pedersen, C., \& O'Campo, P. (2015). Where did she go? the transformation of self-esteem, self-identity, and mental well-being among women who have experienced intimate partner violence. Women's Health Issues, 25(5), 561569. https://doi.org/10.1016/j.whi.2015.04.006

Maxwell, K., Callahan, J. L., Ruggero, C. J., \& Janis, B. (2016). Breaking the cycle: Association of attending therapy following childhood abuse and subsequent perpetration of violence. Journal of Family Violence, 31, 251-258. https://doi.org/10.1007/s10896-015-9765-z

McDonald, S. E., Corona, R., Maternick, A., Ascione, F. R., Williams, J. H., \& Graham-Bermann, S. A. (2016). Children's exposure to intimate partner violence and their social, school, and activities competence: Latent profiles and correlates. Journal of Family Violence, 31(7), 849-864. https://doi.org/10.1007/s10896-016-98467

Miller-Graff, L., Cater, Å. K., Howell, K. H., \& Graham-Bermann, S. (2016). Parent-child warmth as a potential mediator of childhood exposure to intimate partner violence and positive adulthood functioning. Anxiety, Stress \& Coping: An International Journal, 29(3), 259-273. https://doi.org/10.1080/10615806.2015.1028030

Milner, A. N., \& Baker, E. H. (2017). Athletic participation and intimate partner violence victimization: Investigating sport involvement, self-esteem, and abuse patterns for women and men. Journal of Interpersonal Violence, 32(2), 268-289. https://doi.org/10.1177/0886260515585543

Montero, I., Escriba, V., Ruiz-Perez, I., Vives-Cases, C., Martín-Baena, D., Talavera, M., \& Plazaola, J. (2011). Interpersonal violence and women's psychological well-being. Journal of Women's Health, 20(2), 295-301. https://doi.org/10.1089/jwh.2010.2136

Moore, S., \& Diener, E. (2019). Types of subjective well-being and their associations with relationship $\begin{array}{llll}\text { outcomes. Journal of Pchool } & \text { Psychology, 3(2), } & \text { 112-118. }\end{array}$ https://www.journalppw.com/index.php/JPPW/article/view/118

Karayagiz Muslu, G., Coşkun Cenk, S., \& Sarlak, D. (2020). An analysis of the relationship between high school students' tendency toward violence, self-esteem, and competitive attitude. Journal of Interpersonal Violence, 35(23-24), 5976-5996. https://doi.org/10.1177/0886260517723742

Murphy, C. M., Stosny, S., \& Morrel, T. M. (2005). Change in self-esteem and physical aggression during treatment for partner violent men. Journal of Family Violence, 20, 201- 210. https://doi.org/10.1007/s10896-005-5983-0 
Muthén, L.K. \& Muthén, B.O. (1998). Mplus user’s guide. Los Angeles, CA: Muthén \& Muthén

Papadakaki, M., Tzamalouka, G. S., Chatzifotiou, S., \& Chliaoutakis, J. (2009). Seeking for risk factors of intimate partner violence (IPV) in a greek national sample: The role of self-esteem. Journal of Interpersonal Violence, 24(5), 732-750. https://doi.org/10.1177/0886260508317181

Paterson, J., Carter, S., Gao, W., Cowley-Malcolm, E., \& Iusitini, L. (2008). Maternal intimate partner violence and behavioral problems among Pacific children living in New Zealand. Journal of Child Psychology and Psychiatry, 49(4), 395-404. https://doi.org/10.1111/j.1469-7610.2007.01841.x

Riesen, Y., \& Porath, M. (2004). Self-worth and social support of children exposed to marital violence. Canadian Journal of School Psychology, 19(1), 23. https://doi.org/10.7870/cjcmh-2004-0017

Sargent, K. S., Krauss, A., Jouriles, E. N., \& McDonald, R. (2016). Cyber victimization, psychological intimate partner violence, and problematic mental health outcomes among first-year college students. Cyberpsychology, Behavior, and Social Networking, 19(9), 545-550. https://doi.org/10.1089/cyber.2016.0115

Silva, E. P., Ludermir, A. B., Lima, M. C., Eickmann, S. H., \& Emond, A. (2019). Mental health of children exposed to intimate partner violence against their mother: A longitudinal study from Brazil. Child Abuse \& Neglect, 92, 1-11. https://doi.org/10.1016/j.chiabu.2019.03.002

Skeen, S., Macedo, A., Tomlinson, M., Hensels, I. S., \& Sherr, L. (2016). Exposure to violence and psychological well-being over time in children affected by HIV/AIDS in South Africa and Malawi. AIDS Care, 28(Suppl. 1), 16-25. https://doi.org/10.1080/09540121.2016.1146219

Smith, J. R. (2011). Self-worth, shame, and aggression in offenders of domestic violence (Doctoral Dissertation). Retrieved from ProQuest (Order No. AAI3463643).

Tajima, E. A., Herrenkohl, T. I., Moylan, C. A., \& Derr, A. S. (2011). Moderating the Effects of Childhood Exposure to Intimate Partner Violence: The Roles of Parenting Characteristics and Adolescent Peer Support. Journal of Research on Adolescence: The Official Journal of the Society for Research on Adolescence, 21(2), 376394. https://doi.org/10.1111/j.1532-7795.2010.00676.x

Tan, S. Y., \& Wong, T. K. (2012). Existential therapy: Empirical evidence and clinical applications from a Christian perspective. Journal of Psychology and Christianity, 31, 272-277. https:/ /link.gale.com/apps/doc/A342175860/AONE?u=anon $\sim$ d631654d\&sid=googleScholar\&xid=db59 $\mathrm{f} 773$

Teng, Z., Liu, Y., \& Guo, C. (2015). A meta-analysis of the relationship between self-esteem and aggression among Chinese students. Aggression and Violent Behavior, 21, 45-54. https://doi.org/10.1016/j.avb.2015.01.005

Trocme, N., \& Wolfe D. A. (2001). Child maltreatment in Canada: Selected results from the Canadian Incidence Study of Reported Child Abuse \& Neglect. Minister of Public Works and Governmental Services, Ottawa, Canada.

UNICEF. (2020). Violence against children. https://www.unicef.org/protection/violence-against-children

Ugur, H., Constantinescu, P.M., \& Stevens, M.J. (2015). Self-awareness and personal growth: Theory and application of Bloom's Taxonomy. Eurasian Journal of Educational Research, 60, 89-110. https://doi.org/10.14689/ejer.2015.60.6

Walker, J., \& Knauer, V. (2011). Humiliation, self-esteem, and violence. The Journal of Forensic Psychiatry \& Psychology, 22(5), 724-741. https://doi.org/10.1080/14789949.2011.617542

World Health Organization (2013). Global and regional estimates of violence against women: Prevalence and health effects of intimate partner violence and non-partner sexual violence. https://apps.who.int/iris/bitstream/handle/10665/85239/9789241564625_eng.pdf;jsessionid=0564837D EA552089395B36D59BECE7F1?sequence $=1$

World Health Organization (2014). Mental health: A state of well-being. Retrieved from: 
http://www.who.int/features/factfiles/mental_health/en/

World Health Organization (2016). Violence against women. Retrieved from: http://www.who.int/mediacentre/factsheets/fs239/en/

Yıldırım, M., \& Çelik Tanrıverdi, F. (2020). Social Support, Resilience and Subjective Well-being in College Students. Journal of Positive School Psychology, 5(2), 127-135. https://doi.org/10.47602/jpsp.v5i2.229

Yoon, S., Dillard, R., Pei, F., Mccarthy, K. S., Beaujolais, B., Wang, X., Maguire-Jack, K., Wolf, K., \& Cochey, S. (2020). Defining resilience in maltreated children from the practitioners' perspectives: A qualitative study. Child Abuse \& Neglect, 106, 104516. https://doi.org/10.1016/j.chiabu.2020.104516.

Yount, K. M., Miedema, S. S., Martin, C. C., Crandall, A., \& Naved, R. T. (2016). Men's coercive control, partner violence perpetration, and life satisfaction in Bangladesh. Sex Roles: A Journal of Research, 74(9-10), 450-463. https://doi.org/10.1007/s11199-016-0584-3 


\section{About Authors}

Emel Genç. Asistant Proferssor, Bartın University, Bartın, Turkey. emelgenc@bartin.edu.tr

\section{Author Contribution}

This study was conducted by all the authors working together and cooperatively. All of the authors substantially contributed to this work in each step of the study.

\section{Funding}

No funding support was received.

\section{Ethical Statement}

This study was completed in accordance with the Helsinki Declaration. In line with this, the study was permitted by Bartın University, Human Research Ethics Committee.

Ethics Committee Name: Bartın University, Human Research Ethics Committee.

Approval Date: 27/11/2020

Approval Document Number: 2020-SBB-0248 